\title{
A Constituição castilhista de 1891 e a fundação do constitucionalismo autoritário republicano
}

\author{
The "castilhista" Constitution of 1891 and \\ the foundation of republican authoritarian con- \\ stitutionalism
}

Francisco Rogério Madeira Pinto ${ }^{1}$

Resumo: O artigo tem como objetivo identificar uma das matrizes do discurso jurídico autoritário brasileiro no contexto da Primeira República. Aponta, como uma das principais referências para a formação e concretização desse discurso, a Constituição do estado do Rio Grande do Sul, promulgada em 14 de julho de 1891 sob a influência intelectual de Júlio de Castilhos (18601903). Com base no texto constitucional em si e nos debates que anteciparam a sua formulação, aponta-se que a constituição castilhista estabeleceu as bases de uma gramática jurídico-autoritária que iria influenciar outros modelos constitucionais ao longo do período republicano. Trata-se de uma experiência sui generis

1 Professor voluntário do departamento de Direito da Universidade de Brasília. Doutor em Direito, Estado e Constituição pela Universidade de Brasília UnB (2018). Mestre em Ciência Política pela Universidade de Brasília UnB (2006). Bacharel em Direito pelo Centro Universitário de Brasília UniCEUB (2004). Bacharel e licenciado em História pela Universidade de Brasília UnB (1999). E-mail: rogeriomadeirapinto@gmail.com 
para o período, pois já articulava pari passu à formulação da Constituição de 1891, pesadas críticas ao modelo liberal que esta engendrava, estabelecendo-se como antípoda às suas premissas. Na Constituição do Rio Grande do Sul de 1891, encontramos a remissão à ideia de unidade, tema central no discurso antiliberal que será retomado entre os anos 1920 e 1940; o desprezo pelo Legislativo com a consequente absorção pelo Executivo das funções legislativas; a desidratação da representação popular e uma moralização da politica que estabelece a figura do líder político como detentor de virtudes públicas que o legitimam para o mando.

Palavras-chave: Júlio de Castilhos. Constituição do Rio Grande do Sul de 1891. Constitucionalismo autoritário. Fundação.

Abstract: The article aims to identify one of the sources of Brazilian authoritarian legal discourse in the context of the First Republic. It points out, as one of the main references for the formation and concretization of this discourse, the Constitution of the state of Rio Grande do Sul, promulgated on July 14 of 1891 under the intellectual influence of Julio de Castilhos (18601903). Based on the constitutional text and the debates that anticipated its formulation, it is pointed out that the Castilian constitution established the basis of a legal-authoritarian grammar that would influence other constitutional models throughout the republican period. This is a sui generis experience for the period, since it already articulated pari passu to the formulation of the National Constitution of 1891, heavy criticism of the liberal model that it engendered, establishing itself as antipode to its premises. In the Constitution of Rio Grande do Sul of 1891, we find the reference to the idea of unity, a central theme in the anti-liberal discourse that will be retaked between the 1920s and 
1940s; the contempt for the legislative power with the consequent absorption by the Executive of the legislative functions; the dehydration of the popular representation and a moralization of politics that establishes the figure of the political leader as the holder of public virtues that legitimize him to rule.

Keywords: Júlio de Castilhos. Constitution of Rio Grande do Sul of 1891. Authoritarian constitutionalism. Foundation.

\section{Introdução}

Como se estabelece um projeto constitucional de feições autoritárias? Quais os arranjos utilizados para estabelecer a força de uma constituição que, no lugar de limitar os poderes do Estado, fortalece ainda mais suas prerrogativas, em detrimento dos direitos e garantias individuais? A esse modelo constitucional que rejeita a separação de poderes por meio do estabelecimento da prerrogativa do Executivo sobre os demais e da restrição, ao máximo, da representação política pela limitação das garantias dos cidadãos frente ao Estado, denominamos de constitucionalismo autoritário. O século XX é rico em narrativas sobre as maneiras pelas quais foram construídas formas autoritárias de constituições. Nesse sentido, o Brasil da virada do século XIX para o XX apresentou um dos primeiros modelos desse tipo de texto com a constituição do Rio Grande do Sul de 1891.

Este capítulo está dividido em duas partes. Na primeira, procede-se a uma sucinta história desse texto constitucional; na segunda, destacam-se as inovações trazidas pelo texto no sentido de construir um arcabouço jurídico para legitimar um projeto de poder autoritário. Como fontes para a pesquisa, foram utilizadas obras escritas sob a influência castilhista e 
que se propuseram a analisar, bem como defender, a constituição do Rio Grande de 1891. Entre os livros, destacamos as obras História Constitucional do Rio Grande do Sul, de Victor Russomano (1976); Constituição Política do Estado do Rio Grande do Sul: Comentário, de Joaquim Luís Osório (1981) e O Rio Grande do Sul e as suas Instituições Governamentais, de Raimundo de Monte Arraes (1981). Como fontes primárias, foram usados editoriais do jornal A Federação, autointitulado “órgão do Partido Republicano Rio-Grandense" (PRR) e que era responsável pela divulgação dos projetos políticos castilhistas. Em suas páginas, a partir de 23 de junho de 1891, iniciou-se uma série de artigos em defesa das inovações lançadas pelo projeto constitucional castilhista. Apesar de os textos não serem assinados, é alta a possibilidade de terem sido escritos pelo próprio Castilhos, já que este deixa suas atividades como redator-chefe do jornal somente em 20 de julho de 1891, após sua eleição para Presidente do Estado².

É em A Federação que a plataforma castilhista apresenta sua linguagem de combate, afirmativa do projeto que pretendia estabelecer para o Estado. Com base nesses textos, se busca identificar o vocabulário que o autor utiliza para operar seu discurso e indicar, como esse mesmo discurso é rearticulado para fundamentar propostas legislativas de cunho autoritário. Para essa análise, nos apoiamos no conceito de lance, articulado por J. G. A. Pocock. Entende-se por lance quando um autor efetua um ato de fala que inova e atua sobre o contexto linguístico. A expressão, como diz Pocock, sugere um jogo e manobra tática. A sua identificação depende da "nossa compreensão da situação prática na qual ele se encontrava, do argumento que ele desejava defender, da ação ou norma que ele desejava legitimar ou invalidar, e assim por

2 RODRÍGUEZ, 2000, p. 65. 
diante" ${ }^{\prime 3}$. No caso específico da constituição castilhista o lance é estabelecido sobre a linguagem constitucional no sentido de efetivar mudanças de sentido de termos e conceitos caros ao constitucionalismo. Como assinala o historiador inglês, "esses lances podem ser retóricos e implícitos, executados sem alarde e deixados produzindo seus efeitos, ou explícitos e justificados por meio de alguma linguagem crítica, criada para justificar e elaborar seu caráter" ${ }^{\prime 4}$. Quem promove esses lances são atores linguísticos conscientes de seus atos de fala e dos efeitos dos mesmos.

Nesse trabalho, em razão das fontes utilizadas, a identificação do ator linguístico não se limita à figura de Júlio de Castilhos. De forma mais ampla, trabalha-se com um discurso promovido e articulado por vários agentes a partir de uma agenda de poder criada com base na figura de Castilhos e que será denominado por "castilhismo". Desse modo, emprega-se o entendimento que a linguagem não se restringe apenas a uma maneira de falar determinada, mas é essencialmente "um tema de discussão prescrito para o discurso político" ${ }^{5}$, em que se articulam vários agentes para promover o debate discursivo.

O contexto histórico específico trabalhado é o do momento constituinte, ou seja, do processo de discussão e elaboração do texto constitucional. Privilegia-se tal contexto do que a evolução do castilhismo nos anos posteriores. Concentra-se nos argumentos apresentados pelos republicanos-castilhistas vinculados ao Partido Republicano Rio-Grandense (PRR); não privilegiando, portanto, o debate entre estes e os federalistas do Partido Federalista (PRF) a respeito da constituição e do governo castilhista. Aqui,

\footnotetext{
3 POCOCK, 2003, p. 39.

4 POCOCK, 2003, p. 41.

5 POCOCK, 2003, p. 36-37
} 
busca-se o discurso legitimador daqueles que, efetivamente, obtiveram o poder, visando identificar suas estratégias discursivas para validar as inovações autoritárias contidas na constituição. Nesse intuito, mesmo reconhecendo o peso da influência do positivismo comtiano sobre Júlio de Castilhos, este capítulo não se detém sobre o estudo dessa filiação intelectual. Essa influência tem sido bastante pesquisada, com destaque para o trabalho de Ricardo Vélez Rodríguez, Castilhismo: uma filosofia da República.

Parte-se do entendimento de que a constituição estadual de 1891 tem um caráter original, que espelha a concepção de seu idealizador. Por esta razão, concorda-se com o argumento de Gunter Axt ${ }^{6}$ de que a Constituição de 1891 não espelhou uma correspondência automática da filosofia comtiana. Algumas inovações institucionais contidas na constituição corroboram essa tese; entre eles, a concepção de uma Assembleia esvaziada de competências legislativas, quando, para Comte, a Assembleia deveria ser um órgão independente, estruturado por eleições indiretas e representado por estratos corporativos da sociedade. Castilhos, diferentemente, defendia que a ação política é que deveria fomentar a renovação mental e moral na sociedade e não o contrário. Por fim, ao aglutinar os poderes Legislativo, Judiciário, bem como a educação pública, sob a órbita do Executivo, promovia o favorecimento de uma doutrina estatal distante da perspectiva comtiana, a qual reservava à condução mais geral dos rumos da vida social ao Poder Espiritual?.

Ao assinalar essa rearticulação da filosofia positivista promovida por Castilhos, este artigo se propõe a analisar como conceitos caros ao direito constitucional, como tripartição dos poderes, federalismo, republicanismo e repre-

6 2002, p. 12.

7 LACERDA, 2004, p. 74. 
sentação, são reinterpretados tendo em vista a perspectiva de poder unitário estabelecido pela constituição estadual de 1891.

\section{A constituição do estado do Rio Grande do Sul de 1891: Breve histórico}

Após a proclamação da República, o Governo Provisório baixou o Decreto $\mathrm{n}^{\circ} 802$ de 04 de outubro de 1890, que determinava a convocação de assembleias legislativas nos estados e o respectivo processo de eleição para assembleias constituintes estaduais. No projeto de constituição do Governo Provisório, elaborado pela chamada "Comissão dos Cinco" ${ }^{1}$ foi prescrito, além do respeito aos princípios constitucionais, que, nas constituições estaduais, deveriam constar cinco determinações : $1^{\circ}$ - os poderes Executivo, Legislativo e Judiciário deveriam ser discriminados e independentes; $2^{\circ}$ - os governadores e membros da legislatura local seriam eleitos; $3^{\circ}$ - a função da magistratura não seria eletiva; $4^{\circ}$ - os magistrados não seriam demissíveis senão por sentença e $5^{\circ}$ - o ensino seria leigo e livre em todos os graus e gratuito na fase primária. Essas propostas foram encaminhas para uma segunda comissão, a chamada "Comissão dos Vinte e Um", que, após debates, suprimiu os referidos incisos propostos. A retirada dos incisos se deu em razão da influência de Júlio de Castilhos, representante do Rio Grande do Sul no colegiado ${ }^{10}$.

8 A “Comissão dos Cinco" foi nomeada pelo Governo Provisório por decreto, em 3 de dezembro de 1889, para fazer o primeiro projeto de constituição da República. Faziam parte da comissão Saldanha Marinho, Rangel Pestana, Antonio Luiz dos Santos Werneck, Américo Brasiliense de Almeida Mello e José Antônio Pedreira de Magalhães Castro (RUSSOMANO, 1976, p. 172).

9 Todas estabelecidas no art. 62 do projeto (Título II - Dos Estados).

10 RUSSOMANO, 1976, p. 173-174. 
A comissão entendeu que os artigos feriam a autonomia dos estados porque estabeleciam uma rígida simetria entre suas constituições e a da República. De acordo com Assis Brasil, Júlio de Castilhos, como delegado da bancada rio-grandense, apresentou uma emenda supressiva de todas as disposições relativas aos preceitos que deveriam guardar os estados em suas constituições, substituindo a detalhada especificação do projeto pela sucinta determinação de que "os Estados organizar-se-ão livremente, sem ofender os preceitos da Constituição Federal" "11. Por essas intervenções, a ideia federativa da bancada do Rio Grande do Sul definiu a forma de organização dos estados na constituinte, destacando-se, por meio dessas intervenções, o caráter autonomista do projeto de Castilhos, efetivamente posto em prática de maneira singular na constituição do Rio Grande do Sul.

Em 18 de outubro de 1890, foi nomeada pelo governador em exercício, o General de Divisão Cândido Costa, a comissão encarregada de elaborar o projeto de constituição do estado do Rio Grande do Sul. De acordo com o ato $n^{\circ} 498$, a comissão formada para elaborar o projeto era constituída por Ramiro Fortes de Barcellos, Joaquim Francisco de Assis Brasil e Júlio Prates de Castilhos. Ao fim, Júlio de Castilhos foi o único redator do projeto. Os demais não chegaram a colaborar. Ramiro de Barcellos estava na cidade do Rio de Janeiro e Assis Brasil se recusou a assinar o projeto por desacordo com a doutrina ali proposta, considerada por ele como "uma extravagante mistura de positivismo e demagogia"12. Castilhos iniciou a confecção do texto em fevereiro e o entregou no dia 25 de abril de 1891 para o Vice-Governador em exercício, Fernando Abbot.

11 RUSSOMANO, 1976, p. 174

12 Assis Brasil [s.a.] apud AXT, 2002, p. 10. 
Abott convocou a constituinte estadual para 2 de junho e eleições para o dia 5 de maio. A disputa se deu entre o Partido Republicano (PRR) de Júlio de Castilhos e a oposição, coligada sob a legenda do Partido Republicano Federal (PRF). Nesse processo, as fraudes foram notórias e a máquina política montada pelo Partido Republicano impediu qualquer possibilidade de um pleito que oferecesse espaço de uma disputa justa para representantes da oposição ${ }^{13}$, fato que pavimentou o caminho para os movimentos insurrecionais que afligiriam o Estado nos anos seguintes ${ }^{14}$.

As sessões preparatórias para a constituinte do estado começaram no dia 17 de junho de 1891. A comissão formada para oferecer um parecer sobre o projeto da constituição era formada por sete membros, quatro deles médicos, portanto, leigos em matéria constitucional, de maneira que apresentou pequenas modificações ao texto ${ }^{15}$. Mais realistas que $o$ rei, os membros da comissão propuseram que os administradores municipais fossem nomeados pelo Presidente do estado enquanto o projeto de Castilhos previa a eleição dos intendentes e juízes distritais. A justificativa era a de que se deveria "criar um vínculo político entre o governo do Estado e das Municipalidades"16. A proposta não foi aceita, de modo que, assim como os demais pontos, o projeto de Castilhos prevaleceu praticamente em sua íntegra. Os debates sobre o texto foram céleres, iniciando-se em 11 de julho e já a 14 de

13 RODRÍGUEZ, 2000, p. 59-60.

14 Após muita pressão da oposição, somente no ano de 1913, sob o governo de Borges de Medeiros, os federalistas conseguiram eleger um representante para a Assembleia. Em 1917, nova vitória é obtida, resultante de uma mudança no cálculo do quociente previsto em lei para garantir a representação das minorias, o que elevou sua participação para três cadeiras (AXT, 2002, p. 16)

15 AXT, 2002, p. 10.

16 RUSSOMANO, 1976, p. 197. 
julho de 1891, a constituição foi promulgada. Na mesma data, em sessão solene, Castilhos foi eleito governador do Estado.

A partir daí inicia-se um período conturbado para a vida do Rio Grande do Sul. A contestação à constituição de 14 de julho se deu dentro e fora do estado. Em âmbito federal, foram várias as tentativas da oposição para deslegitimar, no Congresso Nacional, a constitucionalidade de um texto que não apresentava simetria com a Constituição Federal ${ }^{17}$. Internamente, essa objeção assumiu a forma de disputas armadas, o que levou o estado a duas guerras civis nas décadas seguintes. A primeira, em 1893, eclodiu com a Revolução Federalista e a segunda com a Revolução de 1923. Somente após o levante de 1923 que o projeto constitucional castilhista sofreria mudanças significativas. Com o Pacto de Pedras Altas, que pôs fim ao conflito, o herdeiro político de Castilhos, Borges de Medeiros, cedeu o poder mediante uma reforma constitucional que suspendeu a reeleição que, até então, praticamente reservava a presidência do estado para os republicanos do PRR. Após as eleições de 1924, que elegeu Getúlio Vargas, o último representante do castilhismo, o equilíbrio de forças na Assembleia foi modificado com o aumento do número de federalistas ${ }^{18}$.

\section{Uma constituição para além de Castilhos}

Apesar de a constituição de 1891 ser claramente ligada à persona de Júlio de Castilhos, seu objetivo era "científico", portanto, acima de uma identificação pessoal. Deste modo, a constituição era um projeto construído para perdurar e articulava-se não à efemeridade de uma vida, buscando pe-

17 AXT, 2002, p. 17-18.

18 AXT, 2002, p. 16. 
renidade por meio da construção de um modelo institucional sólido e bem articulado.

Essa pretensão - de certa maneira concretizada, pois o estado do Rio Grande teria uma nova constituição somente no ano de 1935 - era reconhecida pelos defensores do projeto castilhista e várias obras foram escritas para defendê-lo. Em 1911, Joaquim Luís Osório publica a obra Constituição Politica do Rio Grande do Sul: comentários, considerada como o documento básico do castilhismo ${ }^{19}$. Na obra, Osório defende, ponto a ponto, o texto constitucional. Em 1932, em sua História Constitucional do Rio Grande do Sul, Victor Russomano rechaçava a ideia que a constituição seria uma obra "caprichosa da vontade" ${ }^{20}$, para afirmar que ela tinha raízes históricas e condições de durar no tempo: "Assim também a Constituição Rio-grandense, que consagra o perfeito equilíbrio entre a autoridade e a liberdade, é um momento destinado a perpetuar-se e que recomendará eternamente o nome do seu autor à gratidão dos coevos e ao respeito dos pósteros ${ }^{\prime 21}$

O que essa série de conflitos e disputas em torno da constituição 1891 revela é o reconhecimento que a estrutura de poder que se estabeleceu no Rio Grande do Sul não se assentava exclusivamente na personalidade daquele que exercesse o cargo de presidente do estado, mas, fundamentalmente, na própria constituição. Era a partir dela que se estruturava uma forma de organização que garantia ao ocupante do Executivo os mecanismos adequados para o controle quase que completo da vida política naquele espaço específico. Nesse sentido, e apesar da inspiração terminológica advinda da ideia de uma "ditadura" científica de matriz comtiana, o projeto de poder castilhista procurava se afastar

19 PAIM, 1981, p. 3.

20 1976, p.177.

21 RUSSOMANO, 1976, p. 177, itálicos nossos. 
do estigma de um governo ditatorial, no sentido de um regime constituído, basicamente, pelo arbítrio do governante. A existência de limites impostos em lei é o que diferenciaria uma ditadura de um governo autoritário. Nesse último, o fundamento do poder se encontra na autoridade de quem se legitima pelo reconhecimento de suas alegadas virtudes, seja por meio de eleições ou pela aclamação plebiscitária. Castilhos adotou essa primeira estratégia, como será visto adiante, inaugurando na República a justificação do autoritarismo a partir da lei.

\section{A ideia de unidade como fundamento do go- verno}

A principal marca da Constituição castilhista é ampla prevalência das prerrogativas do Executivo sobre os demais poderes, os quais, ressignificados na linguagem constitucional castilhista, são apresentados apenas como órgãos de um aparelho governativo unitário. No texto, não se fala em poder Executivo, Legislativo e Judiciário, mas da Presidência do Estado, da Assembleia dos Representantes e da Magistratura. Os termos utilizados no lugar da predominante denominação constitucional da existência de poderes independentes e autônomos entre si, conformados para estabelecer o funcionamento harmônico do Estado, destacam não o seu caráter autônomo, mas apenas suas funcionalidades dentro de uma máquina governativa centralizada na figura da Presidência do Estado.

A prevalência das funções executivas sobre as demais pode ser verificada por uma simples contabilidade de artigos e na ordem espacial reservada a cada uma delas. A primeira seção é toda dedicada à Presidência do Estado. Para o que se- 
ria o Executivo, foram reservados 27 artigos e 47 parágrafos. Dentre estes, somente o artigo 20, que trata das atribuições do Presidente, possui 25 parágrafos. Para a Assembleia dos Representantes, foram reservados apenas 15 artigos com 12 parágrafos localizados na seção segunda do documento. Entre estes, destaca-se o Capítulo II, que estabelece as atribuições da Assembleia (Art. 47), fixadas na forma de 7 itens relacionados à sua competência privativa. Para o Judiciário, denominado Magistratura, para a qual se reserva a última posição espacial entre os "poderes", são previstos na seção terceira apenas 11 artigos e também 11 parágrafos ${ }^{22}$.

Na construção do texto constitucional, Castilhos demonstrou grande capacidade técnica, ao estabelecer uma estrutura legal de viés autoritário bem montada, na qual estão articulados os instrumentos legais que garantiriam o controle, por parte do Presidente, de todas as estruturas de poder do estado. Na base dessa engrenagem autoritária, encontra-se o artigo $6^{\circ}$, que, em espaço privilegiado no texto estabelece a centralidade do Executivo sobre os demais poderes.

\section{O pode Uno}

Nas discussões da constituinte estadual de 1891, o deputado Francisco de Paula Lacerda destacava a centralidade do artigo $6^{\circ}$ para o projeto de poder castilhista, assinalando tratar-se de um artigo fundamental para todo o sistema da constituição. Para o autor, o artigo deveria ser discutido como toda a largueza, "visto como da sua acepção ou rejeição depende a aceitação ou não do plano constitucional" ${ }^{23}$. De

22 Todas as referências à Constituição gaúcha de 1891 foram retiradas de Rio Grande do Sul (1895).

23 LACERDA 1891 apud RUSSOMANO, 1976 p. 201. 
fato, artigo $6^{\circ}$ se destacava como o pilar do empreendimento constitucional de Castilhos; a partir dele se articulavam os demais preceitos legais que estabeleciam a construção de um conceito de República estruturada a partir da ideia de Unidade e personificada na figura do chefe do Executivo:

Art. $6^{\circ}$ - O aparelho governativo tem por órgãos a Presidência do Estado, a Assembleia dos Representantes e a Magistratura que funcionarão harmonicamente, sem prejuízo da independência que entre si devem guardar, na órbita da sua respectiva competência, definida nesta Constituição.

No projeto e posteriormente na própria constituição, artigo $6^{\circ}$ não adotava o princípio da separação de poderes e, mais do que isso, não chegava a reconhecer a existência de tais poderes, mas apenas de "órgãos" que funcionariam sob a gerência de um "aparelho governativo". Tanto no próprio artigo da constituição quanto em sua defesa prévia em $\mathrm{AFe}$ deração, numa série de editoriais escritos diariamente entre os dias 23 e 27 de junho de 1891 - portanto antes da instalação da assembleia constituinte -se estabelece uma tentativa inovação e também de diferenciação da linguagem constitucional do período adotada pela Constituição da República. No lugar do arranjo liberal de organização do Estado, tachado como uma "metafísica dominante", preconizava-se uma nova "tecnologia" a respeito do modo como se deve organizar e governar as coisas públicas. Destacava A Federação:

Para que a nova denominação? dizem; porque não manter a classificação adotada geralmente e até na Constituição Federal, que reconhece a existência dos três poderes executivo, legislativo e judiciário?

A tecnologia usual é defeituosa, daí a necessidade de reformá-la, para impedir que se falseie a noção correspondente, por uma interpretação literal.

O que vulgarmente chamam de poderes nada mais são do que órgãos de um mesmo poder. 
A sua divisão é ilusória e não se funda na natureza das coisas. ${ }^{24}$.

Dessas declarações contidas no jornal do partido republicano (PRR), destaca-se o emprego de metáforas corpóreas para descrever o funcionamento do Estado, recurso inspirado no linguajar técnico-científico da sociologia comtiana e sua análise das instituições humanas como um sistema fisiológico ${ }^{25}$. O uso político dessas metáforas orgânicas, que trabalham a simbologia de um "corpo político", é antiga: suas raízes podem ser encontradas desde a Antiguidade. Elas existem no pensamento platônico, ganham vitalidade no período medieval e se estabelecem de forma revitalizada no pensamento político moderno, especialmente nas teorias contratualistas. Nesse sentido, Hobbes é o autor mais representativo sobre o tema ${ }^{26}$. Por meio de seu Leviatã, apresentando-o ainda uma forma sacralizada, Hobbes destaca a ordenação desse corpo por meio de um soberano que está acima da sociedade. Estabelece-se, assim, uma concepção soberanista de organização da política ${ }^{27}$.

Contudo, essas metáforas orgânicas são ressignificadas no discurso castilhista. $\mathrm{O}$ discurso fica no meio do caminho entre uma concepção soberanista da organização política e outra, republicana. Por meio dessa última, o corpo político é entendido como res publica e "tal qual os órgãos e membros de um corpo individual, cada segmento social tem seu próprio lugar e sua função no seio do corpo político da república constitucional" $^{28}$. Em ambas as concepções, sobressai que

24 A FEDERAÇÃO, 1891a. Nas citações de A Federação, optou-se por atualizar a grafia das palavras.

25 LACERDA, 2004, p. 67.

26 Exemplo dessa concepção orgânica do corpo político em Hobbes cf. Leviatã $(1979$, p.5)

27 HARDT; NEGRI, 2005, p. 192

28 HARDT; NEGRI, 2005, p. 192 
somente o "uno" é capaz de governar. A concepção republicana ainda tem raízes em um modelo de organização política que encontra sua forma no Leviatã, pela qual o corpo uno do soberano é representado por uma infinidade de vários outros corpos, mas que lhe complementam enquanto funcionalidades. Apesar de ainda estar ligada a essa perspectiva de um poder que constrói sua unidade a partir da junção de outros corpos, a proposta de castilhista vai além, ao rechaçar a própria possibilidade da existência de corpos que, de alguma maneira, pudessem oferecer alguma alternativa ao poder unificado. Qualquer corpo, por menor que fosse, seria uma ameaça e, nesse sentido, era necessário construir uma imagem de organização do poder em que o corpo político já nasce constituído como corpo único, sem a necessidade de junção de outros para lhe darem substância. É nesse sentido que se deve compreender a especialização dos "órgãos" da constituição castilhista. Eles não são elementos indiferenciados de uma unidade de poder soberano, nem poderes dotados de autonomia, tal como conformados pela doutrina de Montesquieu, mas partes especializadas de um só Poder.

No lugar de corpos, apenas "órgãos" que trabalhariam de forma funcional, mas não competitiva dentro do Estado. O problema destacado pela doutrina castilhista é que a divisão harmônica preconizada pela doutrina liberal seria frágil, bastando que qualquer um deles divergisse dos demais para que fosse instalado o conflito. O resultado é que o poder considerado mais forte, o Executivo, naturalmente dominaria os demais:

E como o mais bem aparelhado para a luta é o intitulado poder executivo, este sempre, como vemos em toda a parte, garante desde logo a sua supremacia, reduzindo a mero simulacro de poder o dos outros dois. O que redunda no que sustentamos em nosso primeiro artigo: que o poder é um, exercitando a sua função por 
órgãos diversos ${ }^{29}$.

Na perspectiva desse discurso fisiológico de organização política, não há que se falar de metáforas mecanicistas que, de alguma forma, possam desnaturalizar o corpo do líder e tratá-lo como "máquina" administrativa. É nesse sentido a reação conservadora de Joaquim Luís Osório às propostas de mudanças do arranjo constitucional:

[...] Pretendem reformar, mas esquecem que a verdadeira reforma é a que melhora, conservando; quando não reformar será demolir e abrir caminho à anarquia ou à retrogradação.

Desconhecem a necessidade de um órgão central em todo sistema político, com se o governo fosse uma máquina e não um organismo vivo, em que os diferentes órgãos se coordenam e cooperam para o fim comum submetendo-se a um superior ${ }^{30}$.

O poder é uno e, por essa razão, não há Legislativo e Judiciário; suas funções são modificadas para serem apenas apêndices ou "braços" de um só poder, corporificado na figura do Presidente do Estado. Nesse sentido, defendia $A$ Federação:

A função governamental é uma, e é exercida por um aparelho, como perfeitamente bem denominaram os autores do projeto. Esta, como todas as funções práticas, subdivide-se, em vista da especialidade dos diferentes fins que tem a preencher.

Daí a necessidade de órgãos diversos, como estabelece a Constituição estudada:

O poder é um, com órgãos diversos, para satisfazer às múltiplas necessidades da função suprema: - governar, isto é, manter a solidariedade, operar a convergência social, de modo que ninguém prejudique o fim capital, o bem público!

[...] Os intitulados poderes legislativo e judiciário não são mais, portanto, do que braços de um só poder, que é aquele que manda,

29 A FEDERAÇÃO, 1891c, p. 1

30 OSÓRIO, 1981, p.10, negritos do autor. 
segundo certos princípios, consagrados em uma Constituição, escrita ou costumeira, e que mantém a harmonia geral, punindo aqueles que violam as leis regularizadoras da coexistência social ${ }^{31}$.

Essa unidade preconizada por Castilhos se apresenta com uma de suas apropriações particulares em relação à doutrina positivista. Comte destacava que não poderia haver uma unificação entre os poderes. Em sua obra, a concepção de poder é mais próxima da ideia de governo, sobre questões relacionadas à realidade da vida material, tendo, portanto, uma eficácia prática ${ }^{32}$. Em sua doutrina, não há a preocupação de se definir "poder" com o refinamento que este conceito assumiria posteriormente na Ciência Política, especialmente após Max Weber, como o uso legítimo da violência. De acordo com Comte, haveria dois tipos de poderes: o poder espiritual ou teórico e o poder temporal ou material. O fundamento do poder temporal seria a força física (violência) e a riqueza, não se estabelecendo uma separação entre poder político e econômico ${ }^{33}$. No entanto, para se manter a coesão social, a violência não pode ser utilizada como única solução; faz-se necessário que seu uso seja justificado. Deste modo, para legitimar o poder temporal, recorre-se ao intelecto e aos sentimentos, que são os fundamentos do poder espiritual. É este último o responsável pela fiscalização, sanção e moderação do poder temporal. É pelo poder espiritual que se atua indiretamente sobre os corações e mentes dos indivíduos, convencendo-os a mudar seu comportamento. Para que se dê o funcionamento harmonioso do governo, é fundamental que esses dois poderes não se misturem, devendo ser estabelecida uma completa separação entre $\operatorname{eles}^{34}$. O risco da unicidade

31 A FEDERAÇÃO,1891a, p.1.

32 LACERDA, 2004, p. 70

33 LACERDA, 2004, p. 71

34 LACERDA, 2004, p. 72 
entre os poderes seria o de gerar um governo teocrático no lugar do estabelecimento do governo positivista:

A primeira condição da autoridade espiritual é a exclusão do poder político, como uma garantia de que a teoria e a prática manter-se-ão sistematicamente separadas. Um sistema em que os órgãos do conselho e os do comando nunca são idênticos não pode, possivelmente, degenerar em qualquer dos males da teocracia ${ }^{35}$

Essa unidade era permitida somente numa situação extraordinária, em casos de distúrbios políticos, quando, para se debelar essa situação, se instalaria, temporariamente, uma ditadura republicana. Na obra Appel aux conservateurs, de 1855, Comte assinala essa excepcionalidade de um poder unificado:

Devo complementar explicando a postura e a extensão da ditadura que pode somente instalar o governo preparatório. Ela indica desde já a separação dos dois poderes, principal base do estado normal, de acordo com sua natureza puramente prática, garantida pela plena liberdade de expressão e a supressão de qualquer orçamento teórico. Mas ela apresenta um carácter excepcional, que, embora conciliável com aquela, tende a alterar, sobretudo em virtude dos hábitos próprios à revolução moderna. Faz-se necessário que a ditadura seja monocrática até que a ascensão da fé positiva tenha modificado de maneira suficiente os costumes para permitir o advento do triunvirato sistemático adequado para a fase principal de transição orgânica ${ }^{36}$

35 COMTE, 1957, p. 367. Tradução livre de "The primary condition of their spiritual authority is exclusion from political power, as a guarantee that theory and practice shall be sistematically kept apart. A system in which the organs of counsel and those of commmand are never identitical cannot possibly degenerate into any of the evils of theocracy".

36 COMTE, 1855, p. 111-2. Tradução livre de "Je dois les compléter en expliquant davantage l'attitude et l'extension de la dictature qui peut seule installer le gouvernement préparatoire. Elle indique déjà la séparation des deux puissances, principale base de l'etat normal, d'aprés sa nature puramente pratique, garantie par la pleine liberte d'exposition et la suppression de tout budget théorique. Mais, elle offre un caractére exceptionnel, qui, quoique conciliabre avec celui-lá, tend à 
A inspiração de Comte para o estabelecimento da ditadura republicana era o modelo romano, bem como a experiência revolucionária de 1789. Na expressão, estão implicadas, ao mesmo tempo, a noção de um governo discricionário de salvação nacional e a ideia de representação simbólica do líder $^{37}$. No entanto, não se trata de despotismo. De acordo com Comte, a ditadura republicana deveria ser algo transitório para restabelecer a ordem em momentos de crises políticas. Tratava-se, portanto, de um dispositivo de caráter excepcional a ser utilizado para debelar a "anarquia" ${ }^{38}$. Somente em situações de crise, como as revoluções, é que a doutrina de Comte permitia que se estabelecesse uma forma de poder monocrático no qual estariam unificados os poderes material e espiritual, como transição para o posterior estabelecimento da integração positiva da sociedade. Essa unificação se daria para fortalecer o poder temporal do ditador em meio a tempos de desordem intelectual e moral. Contudo, de forma alguma esse poder deveria se estruturar por meio da violência. Dever-se-ia se estabelecer, entre o governante e o governado, o pacto de que a ditadura consistiria tão somente em uma medida provisória, com vistas precipuamente à pacificação social. Comte deixa, claro, portanto, que essa supremacia é temporária e que não deverá se consolidar ${ }^{39}$. Nessa transitoriedade, e somente nela, é que o parlamento teria apenas funções orçamentárias. Caso persistam as condições de instabilidade, Comte autoriza a estabelecer que o ditador possa escolher livremente seu sucessor, num tipo

l'alterer, surtout em vertu des habitudes propres à la révolution moderne. Il faut que la dicture reste monocratique jusqu'a ce que l'ascendent de la foi positive ait assez modifié les moeurs pour permettre l'avénement du triumvirat systématique qui convient à la principale phase de la transition organique".

37 CARVALHO, 1990, p. 21.

38 COMTE, 1855, p. 110.

39 COMTE, 1855, p.113. 
de sucessão que denomina como sociocrático, para marcar sua diferença em relação às sucessões teocráticas originárias das monarquias ${ }^{40}$.

O castilhismo faz uma leitura própria desses ensinamentos para estabelecer, numa interpretação enviesada com o intuito de justificar a concentração de poderes no Executivo, que os poderes podem coexistir para estabelecer a unidade por ele preconizada:

A nossa contextura cerebral nos torna suscetíveis de sermos governados de três modos: ou pela influência moral exercida sobre nós, que nos dirige estimulando os nossos sentimentos, ou pelo ascendente intelectual, que nos governa convencendo-nos, ou pela força material, que nos compele ao cumprimento dos deveres que nos cabem na sociedade, quando não nos queremos sujeitar livremente a eles. Desse fato originam-se os três únicos poderes existentes: o poder moral, que aconselha, o poder intelectual, que convence, o poder material ou político, que obriga. Estes três poderes podem coexistir, porque a sua esfera de ação é completamente diversa, o que de outro modo seria impossível ${ }^{41}$.

\section{O federalismo unitário ou a unidade na varie- dade}

No artigo $6^{\circ}$ da constituição estadual de 1891, também se verifica a novidade da introdução - mas não da concepção - de um republicanismo federalista de caráter centralizado. Tratava-se de por em prática a noção de uma "unidade na variedade" ${ }^{\prime 2}$, proposta por Castilhos desde sua participação

40 COMTE, 1855, p.114

41 A FEDERAÇÃO, 1891a, p. 1, itálicos nossos.

42 O termo foi retirado de Russomano (1976, p. 170) em que afirma: "Partindo do critério político federativo, que garante a unidade na variedade, pela descentralização administrativa, sem prejuízo da concentração política, 
na constituinte da República com o objetivo precípuo de estabelecer uma forte e segura autonomia estadual. Castilhos, que, em âmbito nacional, criticava o forte centralismo existente na figura do Imperador, exigia, localmente, a mesma concentração de poderes. Tratava-se de uma defesa intransigente da forma federativa de organização política para os estados que lhes garantisse autonomia política. Em razão da ênfase dada a essa autonomia, a representação rio-grandense passou a ser identificada pelos republicanos ditos "moderados" como defensora de um "federalismo exagerado" ${ }^{43}$. A defesa dos "exagerados" federalistas do Sul visava estabelecer uma retaguarda que lhes protegesse política e financeiramente de intervenções federais. Para isso, era necessário estabelecer a autonomia financeira dos estados frente ao governo central. Nesse sentido, Castilhos foi um ardoroso defensor de uma melhor divisão das rendas provenientes de impostos, a chamada "descentralização de rendas", classificada como questão de "primordial importância" por Castilhos ${ }^{44}$ quando se tratava de se instituir o modelo federativo ${ }^{45}$.

Se os debates travados durante o Império associavam monarquia com unitarismo, refletindo essencialmente a diminuta autonomia provincial frente aos poderes do Imperador, situação constantemente criticada por uma parcela dos liberais, a República, por sua vez, era associada ao fede-

e, portanto, a autonomia da administração local e a ampla existência dos interesses naturais, Júlio de Castilhos chega, como consequência lógica do sistema, à descentralização das rendas" (Itálicos nossos, negritos do autor).

43 RUSSOMANO, 1976, p. 169.

44 RUSSOMANO, 1976, p. 170.

45 Sua atuação na constituinte republicana se pautou em grande medida sobre esse tema e chegou a apresentar um parecer em separado sobre a questão, mas sua proposta não saiu vencedora, perdendo a votação por 123 a 103 (RUSSOMANO, 1976, p. 170-171). Sobre os temas defendidos por Castilhos na constituinte da República cf. Rodríguez (2000, p. 56-9). 
ralismo, portanto, a uma ideia de poder descentralizado ${ }^{46}$. Contudo, as discussões sobre os pares monarquia/unidade e república/descentralidade não se pautavam na questão da concentração de poderes políticos na figura do dirigente local. A discussão dominante se dava a respeito da autonomia das províncias, mas não sobre a forma pela qual os dirigentes dessas províncias exerceriam essa autonomia, ou seja, se iriam repetir, no nível local, os poderes do Imperador, especialmente na forma de um poder moderador capaz de intervir diretamente sobre as respectivas assembleias. No entanto, projeções sobre a possibilidade de um despotismo local já eram existentes e relacionavam a pessoa do "déspota" e a de seu governo a de uma figura disforme, monstruosa, representada na imagem de um corcunda. É nesse sentido que ecoam as advertências de José Bonifácio de Andrada e Silva, ainda no nascer do Império, contra os republicanos federalistas: ${ }^{47}$

‘Estes que não querem ser monárquico-constitucionais, que não podem ser corcundas e que não querem ser republicanos de uma só república, querem um governo monstruoso; um centro de poder nominal, e cada província uma pequena república, para serem nelas chefes absolutos, corcundas despóticos ${ }^{\prime 48}$.

46 LYNCH; STARLING, 2009, p.237.

47 Na discussão sobre o conceito de República/Republicanos entre 1750-1850, Lynch e Starling (2009) destacam que em 1821, sob a influência da Revolução Constitucionalista do Porto, estabelece-se um significado de República como sinônimo de democracia ou de governo popular. Por esta razão, era perfeitamente possível e, assim foi utilizada no período, a expressão monarquia republicana, no sentido de uma monarquia democrática, na qual o povo seria livre, para escolher por meio de eleições, seus representantes no parlamento (LYNCH; STARLING, 2009, p. 213). Por esta razão, é que José Bonifácio se refere a republicanos ditos federalistas, pois estes conviviam com republicanos (democratas) que seriam monarquistas.

48 LYNCH; STARLING, 2009, p. 233. 
Na formulação de José Bonifácio, o federalismo discutido no início do Império seria a base para o despotismo provincial. Essa ideia seria retomada e se desenvolveria ao longo das décadas seguintes. No entanto, a novidade trazida por Castilhos nesse novo período de transição, com o início da República, era o estabelecimento de um "despotismo" de base constitucional; se os "corcundas" eram aqueles que durante o império se voltavam contra a fórmula constitucional ${ }^{49}$ Castilhos, ao contrário, adota a ideia de constituição, se desvinculando da imagem de monstro despótico - tal qual a imagem do Leviatã - estabelecendo, em seu lugar, uma fórmula mais próxima a um despotismo esclarecido por meio da apreensão de conceitos como os de razão, ciência, progresso e bem comum, a ser instituído por meio de uma ditadura republicana. Castilhos opera a transição de um léxico próprio do Antigo Regime, que relacionava despotismo à concentração de poderes em uma só pessoa como um governo despótico - relacionado à imagem de monstruosa de um corpo político disforme - para a de um governo ditatorial, nascido com uma compleição harmoniosa, previamente definida e estruturada a partir de um texto constitucional. O léxico muda, de despótico para ditatorial e, junto a isso, altera-se o modo de se conceber o corpo do governo. As metáforas orgânicas agora passam a ser retiradas da linguagem cientificista do positivismo.

\section{6 antiliberalismo do medo ${ }^{50}$}

A justificação para a unidade se baseava na ideia de medo da desordem, estabelecendo-se o modelo de concen-

49 NEVES, 2003, p. 134-136.

50 A expressão baseia-se no célebre texto de Judith Shklar The liberalism of fear (1989). Nesse texto, Shklar estabelece uma análise do liberalismo como foco no uso do medo e da crueldade na política e na vida social. 
tração de poderes na figura do Presidente do Estado como forma ordenar um estado convulsionado por disputas políticas, mas que tinha como objetivo precípuo fechar as portas do Estado para qualquer tipo de oposição. Se, na vida político-partidária, o inimigo castilhista eram os opositores do Partido Republicano Federal (PRF), antigo Partido Liberal rio-grandense, no campo das ideias constitucionais, o inimigo a ser derrotado era o sistema parlamentar advindo da doutrina liberal.

Antes da proclamação da República, Júlio de Castilhos apontava sua pena para criticar o regime parlamentar ${ }^{51}$. Considerava que o regime republicano não deveria aplicar os processos parlamentares do período imperial. Tal forma de representação, artificial, segundo ele, seria responsável somente por um jogo de transações de caráter meramente personalista que tinha como único objetivo a busca pelo poder, em prejuízo de um projeto que integrasse os interesses do país. A República parlamentar, afirma Castilhos antes de 15 de novembro, "seria substancialmente idêntica ao monarquismo" 52 .

O regime parlamentar era visto como sedicioso, uma disputa egoísta de facções, algo já apontado por James Madison $^{53}$ e Benjamin Constant ${ }^{54}$ na defesa de uma forma de representação política mais restrita, mas que, no discurso castilhista, era motivo para fundamentar o próprio fim do sistema. A vida parlamentar e seus partidos seriam responsáveis por estabelecer o conflito como regra na vida parlamentar. Se para Madison, o remédio para lidar com o faccionismo era a garantia da liberdade, para o discurso castilhista a solução

51 RODRÍGUEZ, 2000, p.61-62.

52 RODRÍGUEZ, 2000, p. 62.

531984 [1788].

541985. 
para tal problema era estabelecer a ordem na forma de um poder centralizado. Nesse sentido, as ideias de liberdade e ordem são consideradas contraditórias. Como resultado dessa articulação, estabelecer-se-ia o distúrbio como resposta concreta, ao se situar, no mesmo espaço ideias consideradas irreconciliáveis. É nesse sentido que se constrói o editorial $A$ Federação. Nele, elencam-se alguns dos países representativos do modelo constitucional parlamentar para demonstrar que, na prática, resulta em anarquia. Inglaterra, França, Bélgica, Itália, Portugal e Estados Unidos são destacados para corroborar como a incompatibilidade entre ordem e liberdade gerou apenas um estado de insegurança que os levava à pobreza, ao conflito e ao despotismo:

A excelência de uma instituição deve ser comprovada pela prática; teoricamente não há instituição má.

Encarada sob esse critério, que triste cópia de si tem dado o constitucionalismo da ponderação de poderes! Até hoje tem sido incapaz de resolver coisa alguma e as nações que o adotaram lutam com as mesmas dificuldades, ainda agravadas, que tentaram remediar com essa ilusória panaceia!

A anarquia lavra intensa como antes, a autoridade enfraquecida e desarmada não consegue às vezes nem garantir a ordem puramente material, os abusos do regime absoluto continuando, a sociedade apavorada, porque não enxerga a quem recorrer no meio da desordem crescente".

$[\ldots]$

Que cegueira é esta que qualifica de garantidora a ordem e da liberdade instituições que patrocinam a exploração de um país inteiro por meia dúzia de fidalgos e algumas centenas de chatins? Ordem e liberdade (que cruel ironia!), numa terra em que as massas se acham convulsionadas até o desespero e escravizadas pela miséria a cobiçosos senhores, como sucede na infeliz Irlanda, e em todo o reino unido!

[...]

A experiência dolorosa de tantos povos não lhes basta, ainda decantam as excelências da cerebrina divisão de poderes que em 
suas cátedras doutoralmente qualificam de suprema garantia da ordem e da liberdade, enquanto na prática, a disparatada instituição gera sendos conflitos, alenta a anarquia, disfarça o despotismo, sistematiza o abuso: que fatal ilusão! $!^{55}$.

As raízes teóricas dessa oposição ao sistema parlamentar teriam origem no positivismo comtiano ${ }^{56}$, mas é na constituição castilhista que se dará sua concretização legal de forma original. Na perspectiva castilhista, os parlamentos são espaços de discussões estéreis, pautados basicamente por interesses pessoais em detrimento do interesse público. A partir daí, constrói-se um discurso para estabelecer que o Executivo é o lugar adequado para a confecção de leis que, de fato, reflitam as necessidades da administração. Em A Federação, as assembleias são descritas como espaços improdutivos e de leviandades, em que "as leis são elaboradas no meio da balbúrdia inerente a esses grêmios" e em que as discussões seriam "perturbadas pelo entrecruzamento dos apartes, onde uma mediocridade qualquer, audaz e bem falante" poderia sobrepujar, em razão de sua oratória, um " pensador, jurisconsulto ou filósofo, profundo no saber, porém menos habituado aos torneios tribunícios ou incapaz para eles" ${ }^{\prime \prime}$. Em que pese toda essa argumentação de matriz platônica contra o caráter argumentativo e retórico próprios da política, cuja consequência seria o encobrimento da verdade ${ }^{58}$, o discurso castilhista buscava apresentar suas propostas como algo eminentemente moderno, como resultado das necessidades atuais de seu tempo. A argumentação baseava-se no entendimento que o executivo era o lugar apropriado para a ação legislativa porque concentrava, em sua órbita, um

55 A FEDERAÇÃO, 1891d, p.1.

56 RODRÍGUEZ, 2000, p. 36.

57 A FEDERAÇÃO, 1891b, p.1, itálicos no original.

58 ARENDT, 1993, p. 91-92 
corpo técnico capaz de elaborar uma legislação adequada às necessidades reais da administração ${ }^{59}$ :

No mundo moderno, em toda a parte vemos os chefes de Estado, por si ou influenciados pelos homens mais eminentes, formulando as legislações mais adequadas aos respectivos países, tendo-se em vista as luzes e circunstâncias do tempo: salvo esse grau de imperfeição inerente a todas as obras humanas, pode afirmar-se que, na quase totalidade dos casos, foram muito acertadas as leis postas em vigor pelos governos extra-parlamentares" ${ }^{100}$.

O liberalismo e sua organização institucional são apresentados como "metafísica", ideias desencarnadas da realidade e que não encontrariam naquele corpo político, possibilidades de desenvolvimento sadio:

A metafísica dominante, obrigada a abordar o problema governamental, que há muito reclama solução, imaginou uma outra divisão de poderes.

Arvorando em sistema político definitivo o regime inglês, fez da separação de poderes e ponderação dos três intitulados poderes, executivo, legislativo e judiciário, chave do sistema ${ }^{61}$.

De acordo com editorial de $A$ Federação, essa distinção não encontraria acolhida na "ordem natural das coisas", pois estabelecia uma separação de poderes que iria de encontro a uma racionalidade administrativa qual preconiza que a lei e sua execução deveriam ter a mesma origem:

[...] é incontestável que o mais apto a pôr em prática uma coisa é a própria pessoa que a concebeu [...] Só na arte política é que se quer separar irracionalmente duas funções correlatas, privando a quem compete manter a ordem pública da faculdade de conceber

59 Essa perspectiva ganharia cada vez mais espaço nas décadas seguintes, com destaque para Francisco Campos (2001) e sua obra O Estado Nacional, publicado em 1941.

60 A FEDERAÇÃO, 1891c, p. 1.

61 A FEDERAÇÃO, 1891a, p. 1. 
os meios de realizá-la, como são as leis ${ }^{62}$.

A divisão de poderes de vertente inglesa seria "artificial", pois não poderiam coexistir concomitantemente três poderes na ordem política. Essa divisão fatalmente seria fonte de conflitos e concluía que "seja como for, às claras ou disfarçadamente, a função legislativa reúne-se à executiva pela força das coisas, e apesar de todas as combinações humanas" ${ }^{63}$.

Os fundamentos desse editorial, publicado em 23 de junho, seriam reforçados na sessão de abertura dos trabalhos do congresso constituinte do estado, no dia 25. Em mensagem para a Assembleia, o vice-governador em exercício, Fernando Abbot, assinalava, arrimando-se no passado político do Rio Grande do Sul, a desnecessidade de um parlamento com funções legislativas:

Na elaboração desse projeto, procurei inspirar-me nas verdadeiras necessidades do Rio Grande do Sul, interpretando-as à luz do critério que me sugeria o seu longo passado político, onde a esterilidade do regime parlamentar e a perturbadora divisão do legislativo e executivo punham em evidência a sua absoluta imprestabilidade como sistema de governo" ${ }^{\prime \prime}$.

Para evitar os conflitos que poderiam advir da separação dos poderes, a solução constitucional encontrada foi a de concentrar as funções legislativas e executivas na figura do Presidente. Sua função seria pacificadora dado que o parlamentarismo, nas palavras de um constituinte estadual, Paulo Alencastro, "foi sempre um estorvo à marcha do progresso e um obstáculo poderoso à realização das grandes ideias" ${ }^{65}$.

62 A FEDERAÇÃO, 1891a, p. 1.

63 A FEDERAÇÃO, 1891a, p. 1.

64 A FEDERAÇÃO, 1891b, p. 1.

65 RUSSOMANO, 1976, p. 214. 


\section{O esvaziamento da função parlamentar}

Essa concepção antiparlamentar definiu a esvaziada função que teria o parlamento local, redefinido como uma Assembleia de Representantes de atribuições tão somente orçamentárias, que consistiam, basicamente, na votação de créditos financeiros e no exame da aplicação das rendas públicas (art. 46 da Constituição).

Essa redefinição do papel institucional da Assembleia foi uma das realizações mais arrojadas da constituição do Rio Grande do Sul e constituía, como afirmando pelo constituinte Francisco G. Amaral, o ponto radical da reforma proposta por Castilhos ${ }^{66}$. A radicalidade da proposta residia porque, primeiro, se opunha à divisão dos poderes inserida nas constituições desde o século XVIII e adotada pela Constituição Federal e, segundo, no sentido de ser a raiz da estrutura de poder construída por Castilhos. Deste modo, ao se juntarem os artigos $31^{\circ}$ a $34^{\circ}$ ao artigo $6^{\circ}$ do texto constitucional, articulam-se as peças da engrenagem constitucional castilhista. Nesses artigos, encontram-se os instrumentos legais que garantiriam o controle, por parte do Presidente, de todas as estruturas de poder do Estado para estabelecer os fundamentos do poder republicano unitário.

Os debates sobre o tema foram intensos ao tempo da constituinte ${ }^{67}$. Contudo, como os demais, os artigos do projeto não sofreram quaisquer modificações ao serem transpostos para a constituição. Nos comentários sobre o tema em $A$ Federação, os argumentos apresentados antecipavam as falas dos constituintes. Apontava que a razão da transferência das funções legislativas para o Executivo visava evitar

66 RUSSOMANO, 1976, p. 214.

67 OSÓRIO, 1981; RUSSOMANO, 1976. 
possíveis lutas e disputas que, fatalmente, se dariam entre esses poderes, concluindo que o poder executivo, por ser o mais aparelhado para governar, deveria prevalecer entre os demais: "E como o mais bem aparelhado para a luta é o intitulado poder executivo, este sempre, como vemos em toda a parte, garante desde logo a sua supremacia, reduzindo a mero simulacro de poder o dos outros dois" 68

Uma nova forma de representação era estabelecida. $\mathrm{O}$ republicanismo castilhista retirava as funções legislativas do parlamento para concentrar na figura do Presidente as principais prerrogativas do Estado. A fundamentação para tamanha concentração de poderes estava na construção da imagem do chefe do Executivo como a encarnação da virtude pública, único capaz de concretizar o bem comum. Para constituir essa representação, ancorada na mística de um líder virtuoso, foi necessário estabelecer no texto constitucional um silêncio sobre o modelo liberal de representação parlamentar já no artigo $1^{\circ}$ da Constituição:

Art. 1. - O Estado do Rio Grande do Sul, como um dos membros componentes da União Federal Brasileira, constituiu-se sob o regime republicano, no livre exercício da sua autonomia, sem outras restrições além das que estão expressamente estatuídas na Constituição da República dos Estados Unidos do Brasil.

No artigo não há qualquer referência ao conceito de representação. Esse é um dos silêncios mais eloquentes do projeto castilhista, ponto que não passou despercebido ante as discussões que se travaram desde o projeto da constituição e que se seguiram nos anos seguintes. O debate ao tempo da constituinte fundamentava-se em dois temas principais. O primeiro apontava a negação do caráter republicano da constituição ante a ausência do elemento representativo,

68 A FEDERAÇÃO, 1891b, p. 1. 
uma vez que o conceito de República estava ligado à ideia de governo popular eletivo. O segundo, como consequência imediata do primeiro, assinalava a falta de paralelismo entre a constituição estadual e a federal. A controvérsia perdurou, o que demonstra a resistência e mesmo vigor do projeto constitucional castilhista, que, estruturado para perdurar, foi defendido ao longo de vários anos ${ }^{69}$.

Se num primeiro momento, a ausência da palavra representativo para qualificar o regime político do Rio Grande do Sul era reconhecida, e até mesmo justificada como estando de acordo com a Constituição Federal, anos mais tardes Monte Arraes $^{70}$ justificaria a ausência afirmando que não se tratava de uma ausência propriamente dita, mas de uma presença ficta, pois, no conceito de república adotado pela constituição do Rio Grande do Sul, já estaria incluída a ideia de representação. Dessa forma, verifica-se que os argumentos mudaram e passam a ter com base o reconhecimento da importância da representatividade nos modelos constitucionais. Nesse ponto, a defesa da constituição castilhista adaptou seu discurso para inserir a existência da representação, utilizando-se, inclusive, de argumentos retirados do modelo liberal:

Nesta transfusão de formas, a expressão "representativo" como a significação que tem no sistema inglês, tornou-se imprópria por insuficiente para designar a maior amplitude que assumiu, na América o regime de representação, com a adoção da forma republicana. E foi em virtude dessa evolução histórica que a palavra republicano tornou-se nas Américas sucedânea da expressão representativo no sentido britânico, e entrou a desempenhar, para exprimir a origem e organização dos poderes, o mesmo papel que esta ultima desempenhara no organismo constitucional inglês.

69 Cf. Russomano (1976, p. 199) traz alguns exemplos dessas defesas ocorridas no parlamento nacional, tanto do caráter republicano e como da adequação da constituição estadual aos princípios da constituição federal.

701981. 
[...] Na América, a palavra "república" inclui em si o princípio de representação inerente à estrutura política dos seus governos. Esclarecida assim a verdadeira acepção das palavras "representativo" e "republicano", podemos afirmar que o constituinte rio-grandense se conduziu com maior ciência e consciência, ao formular o art. $1^{\circ}$ da sua carta política, do que o constituinte federal ao redigir o artigo correspondente da carta constitucional da República ${ }^{71}$.

Na década de 1930, esses argumentos se renovam e passam a ter mais força no contexto de crítica ao liberalismo. Russomano, em distante obra de 1932, defende o modelo restritivo de representação proposto por Castilhos. Nesse sentido, rebatia os argumentos de Rui Barbosa e sua afirmação de que a distinção da forma republicana federativa ou não, baseava-se, além da existência dos três poderes constitucionais (Legislativo, Executivo e o Judiciário), que os dois primeiros, obrigatoriamente, seriam derivados da eleição popular. Contra esse raciocínio, Russomano se utiliza do pensamento de Sampaio Dória, cuja obra Princípios Constitucionais de 1926 afirmava que o que constitui e singulariza o regime republicano seria a eleição do Chefe de Estado pelo povo ${ }^{72}$. Nesse ponto, Russomano retoma o argumento da unidade de poder. Para ele, não desnaturava a forma republicana a ausência de uma divisão de poderes; ao contrário, seria da essência da República a existência de um governo unificado representado pela figura do Chefe de Estado.

\section{A virtude do líder é a fonte da lei}

Além de ser o espaço adequado para a criação das leis, seria na função executiva que se aglutinariam, na figura do

71 ARRAES, 1981, p. 27-28, aspas do autor.

72 RUSSOMANO, 1976, p. 200. 
Presidente, as condições morais necessárias para se gerir a coisa pública. Essa moralidade se apresenta nos textos como expressão de uma virtude pessoal, expressa pela capacidade intelectual do líder e de seu desinteresse pelo enriquecimento pessoal. Por reunir tais virtudes, o líder político é capaz de estabelecer a representação dos valores públicos de determinada comunidade ${ }^{73}$. Nesse sentido, na figura do Presidente unifica-se moral e ética como um dos esteios legitimadores de seu poder.

Castilhos, assim como seus sucessores na Presidência do Estado, se apresentava como detentor dessa virtude pessoal que, por si, os qualificava para o encargo que estavam a exercer. Em mensagem à Assembleia do Rio Grande do Sul, Castilhos afirmou:

Se porventura me pode ser atribuído algum mérito, este consiste unicamente na imaculada pureza de intenções com que tenho procurado tornar-me órgão fiel das aspirações republicanas e devoto servidor do Rio Grande do Sul, minha estremecida terra natal, que me domina pelo mais profundo afeto e que pode exigir de mim todos os sacrifícios pessoais pela sua felicidade"74.

Castilhos buscava infundir a ideia que a organização político-constitucional que estava construindo para o Rio Grande iria estabelecer um "regime da virtude". Nela, estariam aptos a governarem, não necessariamente aqueles eleitos para a função, mas a figura que demonstrasse sua "pureza de intenções" e desinteresse pessoal em favor do bem público. Nesse concerto, o bem público somente seria alcançado por um líder virtuoso, que, ao dirigir um Estado forte, estabeleceria a completa reorganização político-

73 Para uma discussão mais detalhada sobre o conceito de virtude e bem público no castilhismo cf . Rodríguez (2000), especialmente o capítulo VII, O bem público interpretado como o "reino da virtude".

74 A FEDERAÇÃO 1897apud RODRÍGUEZ, 2000, p. 105, grifos do autor. 
-administrativa do Estado, a prosperidade material e uma educação cívica moralizadora. Ao articular sua capacidade moral com o interesse ético de um bem público, Castilhos apresentava a figura do Presidente como um ente esclarecido e moralizante, que colocava os interesses do Estado acima dos interesses individuais ${ }^{75}$. O progresso moral e intelectual seria alcançado por meio de uma ordem ditatorial, por meio da ação do Estado. Como destaca José Murilo de Carvalho "eis um ideal de despotismo ilustrado que tinha longas raízes na tradição-luso brasileira desde os tempos pombalinos do século XVIII" 76 .

É nesse esteio moral, articulado a uma concepção de bem público, que Castilhos buscou estabelecer o primeiro fundamento de sua legitimidade, que se completaria quando finalmente transmutada em lei. Seria a virtude, mais do que a escolha pela eleição, que o habilita a governar de maneira quase imperial, ou nas palavras dele, de maneira suprema como consta no artigo $7^{\circ}$ da Constituição: “A suprema direção governamental e administrativa do Estado compete ao Presidente, que a exercerá livremente, conforme o bem público, interpretado de acordo com as leis" 77 .

Em texto de abertura em A Federação, é possível verificar como se construía esse raciocínio, que articulava ordem à existência de um poder autônomo, moralizado e moralizador, por meio de uma educação cívica a ser implantada:

Já o dissemos e não nos cansaremos de repeti-lo: a plena regularização da vida pública, como da privada, só é possível, com uma inteira regeneração dos costumes, mediante uma educação nova, abraçando todos os aspectos da vida humana.

75 RODRÍGUEZ, 2000, p. 115.

76 1990, p. 27.

77 Itálicos nossos. 
Só esta operação fundamental trará a harmonia social que todos desejamos. Para isto é preciso que exista um poder independente, que instrua e governe as consciências, convencendo; para isto é preciso que uma cultura moral mais intensa permita a intervenção do poder que apela e convida amavelmente, que modifica a nossa conduta, que nos arrasta a proceder bem, movendo os nossos bons sentimentos em favor daquilo que quer fazer vingar"78.

A questão é como juridicizar esse valor moral e passar de uma ética para o direito? O primeiro passo se dá pela construção da imagem do líder como encarnação dos valores morais capazes de regenerar os costumes e construir a harmonia social. Depois, a construção das bases institucionais para alavancar esse ente moral a uma instituição. Para isso, Castilhos estabelece, no texto constitucional, um processo de caráter racional por meio de um procedimento legislativo circular.

\section{Processo (legislativo) circular e representação viciada}

De acordo com o artigo $7^{\circ}$ da constituição, a suprema direção do governo caberia ao chefe do Executivo, que o exerceria de forma livre, tendo como limitação apenas o interesse público, interpretado de acordo com as leis. A adjetivação estabelecida para dar destaque às prerrogativas do chefe do Executivo revela a estrutura em que se assentava na administração do Rio Grande: um poder supremo, em nome do bem público, estabelecido a partir da lei. A gênese desse poder, portanto, não se assentava, como no constitucionalismo liberal, no povo, população, nação ou qualquer outra fórmula conceitual que se queira oferecer para destacar que a gênese do poder deveria vir do assentimento da maioria

78 A FEDERAÇÃO, 1891b, p. 1. 
dos que habitam determinada comunidade política. A constituição castilhista, portanto, não adotou o modelo de poder soberano que se desenvolveu a partir de uma pressuposta vontade popular. A fonte e legitimidade de seu poder provinha de um procedimento formal de produção de leis que institucionalizava uma autorreferida superioridade moral e intelectual de um líder capaz de estabelecer o bem público. Essa argumentação, substituindo por vezes a figura isolada de um líder por uma formação coletiva na forma de uma elite, com mais ou menos sofisticação, foi adotada pelo discurso autoritário brasileiro a partir de então ${ }^{79}$.

A estratégia de fundamentação dessa argumentação relaciona a soberania à lei. Estabelece, por um lado aquilo que Jurgen Habermas chama de legitimidade positivista. Por outro, estrutura-se num arranjo em que a moral individual do líder estabelece-se com a base de uma forma de representação simbólica. No contexto, Habermas não se refere ao positivismo filosófico comtiano, e sim ao positivismo jurídico, para estabelecer um tipo de legitimidade que se assenta não na vontade popular, masque se legitima apoiando-se exclusivamente em qualidades formais próprias, estabelecidas por meio de um processo institucionalizado juridicamente. Para Habermas, Weber teria introduzido um conceito positivista do direito, por meio do qual o direito seria aquilo que o legislador, democraticamente legitimado ou não, estabelece como tal ${ }^{80}$. No caso castilhista, essa legitimação positivista se estruturava de forma circular ao articular as instituições responsáveis pela formulação das leis à figura do Presidente. O percurso legislativo partia do Presidente, seguia para as esferas consultivas municipais e retornava para o próprio Presidente.

79 Para a reprodução desse discurso na ditadura militar cf. BARBOSA, 2009, p. 25.

80 HABERMAS, 2011, p. 193. 
A Constituição do Rio Grande reservava seu capítulo VI para apresentar esse processo sui generis de criação de leis. O Art. 31 garantia ao Presidente do estado a prerrogativa de elaboração dos projetos de leis, não cabendo à Assembleia dos Representantes qualquer participação na elaboração, discussão e aprovação de propostas legislativas. Os projetos de lei eram enviados diretamente aos intendentes municipais $\left(\S 1^{\circ}\right)$, responsáveis por recolher, durante três meses, possíveis propostas dos cidadãos ao projeto $\left(\$ 2^{\circ}\right)$. Ao chegar à esfera municipal, o projeto encontrava um ambiente que lhe era amplamente favorável, dada a manipulação que o governo do Estado exercia sobre as eleições dos intendentes e dos conselhos municipais ${ }^{81}$. Não havia propriamente uma análise das propostas enviadas pelo Presidente, sendo vedada ao âmbito municipal qualquer prerrogativa para suprimir artigos relativos aos projetos de lei. Cabia à municipalidade apenas propor emendas ou observações aos projetos. Ao retornarem ao presidente, ficava a cargo de sua discricionariedade a aceitação ou não das propostas lançadas pelos cidadãos $\left(\S 3^{\circ}\right)$. Passado o prazo para apresentação das propostas e do exame do Presidente, o projeto era convertido em lei $\left(\$ 4^{\circ}\right)$.

Com esse processo, Castilhos buscava garantir racionalidade a um processo legislativo estruturado sobre bases representativas extremamente limitadas. Ao transferir para o ente municipal a possibilidade de alguma margem de apreciação de seus projetos de lei, e não para uma assembleia legislativa estadual que lhe fosse comparada em estatura, Castilhos, estava apenas garantindo a publicidade de seus projetos legais. Desse modo, suas propostas não ficariam sujeitas a qualquer tipo de interferência que não dele próprio. Por esta razão, não se poderia falar nem de um dito caráter plebiscitário do processo legislativo, como defende

81 RODRÍGUEZ, 2000, p. 139. 
Rodríguez $^{82}$, dado que não se abria, sequer, a possiblidade de uma resposta negativa à consulta popular. O projeto constitucional de Castilhos não apresentava brechas que pudessem oferecer aberturas em seus flancos institucionais. Nele, o líder, como corpo moral, é a fonte do direito. E este se constitui na forma de projetos de lei que circulam em meios consultivos de reduzida capacidade de modificação e que retornam para o Presidente juridicizar as propostas. Estabelecem-se por esse mecanismo circular de produção legal duas exigências do direito moderno: um procedimento legislativo racional para a produção de leis e um mínimo de representação.

Apesar dessa estrutura legislativa sui generis, o discurso castilhista buscava afastar-se da ideia de um governo tirânico, no sentido de fundamentar-se apenas no arbítrio do governante. Assinalava, nesse sentido, que suas decisões sofriam limitações legais. Duas seriam as restrições a que estaria submetido o chefe do executivo: uma orçamentária e outra pela opinião pública. Afirmava A Federação:

Por um lado, o poder limita-se, negando-se-lhe o arbítrio na aplicação dos dinheiros públicos, não podendo gastar-se num ceitil sem permissão legal ou fora das verbas do orçamento; por outro lado, o poder limita-se ainda, restringindo-se a faculdade de decretar os preceitos que regulam a existência social, de jeito a impedir-se a menor tirania, o estabelecimento de leis retrógadas ou em desarmonia com o pensamento geral: fecham-se as duas únicas portas ao despotismo; é o advento do único governo possível dentro de tais condições, o governo de opinião e do bem público" ${ }^{\prime 13}$.

O que esse discurso buscava lançar é que, apesar das inovações com vistas a fortalecer o Executivo e esvaziar o poder representativo do legislativo local, a constituição se

82 2000, p. 139.

83 A FEDERAÇÃO, 1891c. 
apresentava como uma garantia legalista para um manejo autoritário do Estado. Utilizando-se de uma fórmula legalista, afirmava-se que a centralização do poder contido no texto, não estabeleceria uma execução arbitrária de poder, pois na constituição estaria o essencial para o afastamento de um poder tirânico: a existência de instrumentos institucionais de limitação de poderes.

\section{O fechamento constitucional}

O discurso castilhista encobria o fechamento institucional estabelecido pela constituição com o intuito de cerrar qualquer abertura que pudesse ameaçar a unidade do poder centrada no Executivo ${ }^{84}$. Para tanto, o projeto institucional castilhista estabeleceu dois fechamentos. O primeiro, interno, foi estabelecido dentro do próprio texto constitucional com o objetivo de isolar o centro do poder de qualquer intromissão de qualquer fonte representativa; o segundo fechamento, externo, era direcionado às oposições político-partidárias e mesmo para indivíduos nascidos em outros estados.

Para o fechamento interno, foram estabelecidos mecanismos que impediam que qualquer outro representante dos demais poderes, tratados apenas como meros órgãos de um executivo hipertrofiado, pudessem, mesmo provisoriamente, adentrar na estrutura de tomada de decisões do Estado.

84 Para a discussão sobre fechamento e abertura constitucional, nos valemos da análise de Carvalho Netto (2007, p. 9) que afirma que a história do constitucionalismo se estabelece "como um tenso processo aberto de permanente inclusão, porque sempre exclui. Aqueles que não têm a sua diferença específica reconhecida como igualdade levantarão sua pretensão de reconhecimento como direito à igualdade [...]. Essa nova inclusão, no entanto, outra vez fecha o círculo daqueles que reconhecemos como titulares dos direitos fundamentais, o que dará visibilidade a novos excluídos que, a seu turno, levantarão a sua pretensão à igualdade". 
Deste modo, por meio dos artigos 10, 11 e 12, Castilhos delegou ao Presidente o poder de preencher pessoalmente os cargos que tivessem a prerrogativa de assumir a Presidência quando esta estivesse vaga por algum motivo. Na cadeia substitutiva, encontrava-se o Vice-presidente, escolhido pelo próprio Presidente, dentro de um prazo de seis meses após sua eleição $\left(\operatorname{art.} 10^{\circ}\right)$. Para a substituição do Vice-Presidente, Castilhos estabelece outra inovação. No lugar do substituto ter origem de outros "poderes", a constituição estabelecia que eles sairiam dos quadros do próprio Executivo (art. 11). Esse concerto acendeu algumas críticas no processo constituinte. O deputado Alencastro Carneiro de Fontoura apresentou declaração nesse sentido: "Penso também que o substituto do vice-presidente do Estado não devia ser um dos secretários do presidente ou vice-presidente, quando no poder. Parece-me que devia ser o presidente do Tribunal Superior, o intendente municipal ou o desta casa ${ }^{85}$.

Contudo, todas as propostas contra a fórmula prescrita por Castilhos foram rejeitadas e o texto ficou estabelecido como constava no projeto original.

No que concernia à relação com as oposições, a constituição garantia ao Presidente a capacidade de produzir uma legislação que dificultava seu acesso ao poder. Como resultado, na Assembleia dos Representantes, predominava o monolitismo eleitoral do PRR, pois a quase totalidade dos parlamentares eram desse partido, em razão da manipulação dos resultados das eleições pelos castilhistas ${ }^{86}$. Junte-se a isso o uso ostensivo das forças de segurança do Estado para impedir a organização da oposição ${ }^{87}$ e criava-se o ambiente propício não à ordem preconizada por Castilhos, mas à de-

85 Apud RUSSOMANO, 1976, p. 205

86 RODRÍGUEZ, 2000, p. 60.

87 RODRÍGUEZ, 2000, p. 76. 
flagração de graves conflitos políticos sofridos pelo estado do Rio Grande do sul. Do período iniciado com o início da República, em novembro de 1889, ao fim do governo de Castilhos, em janeiro de 1898, o governo do estado teve dezoito governadores. Destaca-se, nesse período, a deposição de Castilhos da Presidência do estado em 02 de novembro de 1891, que ficou sob o comando do que ele denominou de "governicho" até o seu retorno em 25 de janeiro de $1893^{88}$. Como ápice desse processo de exclusão das oposições, entre 1893-1895, explode a Revolução Federalista, que deixou um saldo de dez a doze mil mortos numa população, à época, de um milhão de habitantes. Após a morte de Castilhos, sob o governo de Borges de Medeiros, seu herdeiro político, os frutos desse fechamento desembocaram na Revolução de 1923.

O artigo 12 da constituição estabeleceu, também, outra forma de fechamento externo constitucional: o nativismo. De acordo com o artigo, somente rio-grandenses natos poderiam assumir os cargos de Presidente e Vice-Presidente. Novamente, algumas reações se deram entre os parlamentares ante a uma inovação que, se afirmava, não constava em nenhuma outra constituição estadual ${ }^{89}$. Houve reações, também, da comunidade de imigrantes como no caso da representação do cidadão Ernesto Reinhold Ludwig, dirigida ao congresso constituinte ${ }^{90}$.

88 Sobre as disputas que levaram à queda de Castilhos, implantação do "Governicho" e seu retorno ao poder cf. Rodríguez (2000, p. 63-76).

89 Nesse sentido a manifestação do deputado Vasco Bandeira: "Por que essa exclusão? Para que tornar dependente o primeiro cargo do Estado de um acaso de nascimento? Este princípio não é consagrado em nenhuma outra Constituição e me parece que o artigo não conseguirá o fim que teve em vista". (RUSSOMANO, 1976, p. 206).

90 RUSSOMANO, 1976, p. 206. 


\section{Considerações finais}

O castilhismo teve como um de seus fundamentos o culto à personalidade de seu fundador. Contudo, dá um passo à frente, ao estabelecer, com o uso do meio jurídico e da forma constitucional, os fundamentos do autoritarismo político. Por meio da constituição do Rio Grande de 1891, direito e política são articulados num texto em que se pode encontrar as matrizes de uma concepção jurídica que fundamenta o autoritarismo: hipertrofia do executivo, retirada ou limitação da função legislativa dos parlamentos, diminuição ou mesmo negação da representação política, fechamento institucional às oposições ou aceitação de oposicionismo limitado, articulação de um discurso moralizante e moralizador como forma de legitimação das lideranças e estabelecimento de processo legislativo viciado como forma de oferecer racionalidade à produção de leis.

Todos esses arranjos se encontram nos artigos que compõem a constituição gaúcha. $\mathrm{O}$ artigo $6^{\circ}$ é a base desse sistema jurídico que buscou adaptar, e mesmo transformar, a linguagem constitucional de seu tempo, já que rechaçava a teoria da divisão de poderes de matriz liberal para uma perspectiva de poder político concentrado. Por meio de mudanças na linguagem constitucional, construída ante facto, buscou-se estabelecer e justificar as mudanças políticas que se dariam sob a presidência de Júlio de Castilhos e de seus sucessores. Agiu-se de forma estratégica; primeiro, construindo-se uma nova gramática constitucional pautada na ideia de unidade. A estratégia adotada foi a de mudar as instituições para se alterar uma prática, não o contrário. Aqui, a linguagem vinha antes da ação, já que estabelecia um novo vocabulário político, constituído com a ressignificação de conceitos já conhecidos. Verifica-se a estratégia de proceder 
deslocamentos conceituais por meio de ações como "torcer significados", "alterar vocabulários", "fazer associações incomuns e se utilizar de artimanhas argumentativas", tudo para tentar estabelecer uma linguagem própria ${ }^{91}$.

O resultado mais claro do projeto castilhista foi a juridificação de um discurso político. Castilhos, apropriando-se de forma muito particular da doutrina de Comte, adaptou-a para seus objetivos, estabelecendo sua positivação jurídica. Nesse sentido, procede a articulação de dois conceitos de positivismo, o de matriz comtiana e o jurídico. Desse último, se utiliza de um processo racional de produção das leis como meio para garantir uma legitimidade que se ampara no processo legislativo. Do primeiro, apoia-se numa legitimidade estruturada na representação simbólica do dirigente apresentado como personificação da virtude pública. Por fim, Castilhos construiu o fundamento do constitucionalismo autoritário por meio da junção do formalismo jurídico-normativo articulado a um discurso moralizador.

\section{Referências}

A Federação. Porto Alegre. Eds. 145, 146, 147. 1891a, 1891b, 1891c. Disponível em: http://bndigital.bn.gov.br/hemeroteca-digital/.

AMARAL, Azevedo. O Estado autoritário e a realidade nacional. 1938. Disponívelem:http://bdjur.tjce.jus.br/jspui/ bitstream/123456789/118/1/AMARAL, \%20A\%20O\%20 estado\%20autorit\%C3\%A1rio.pdf. Acessado em: 25 de julho, 2016.

ARRAES, Raimundo de Monte. O Rio Grande do Sul e as suas Instituições Governamentais. Biblioteca do pensamento

91 JASMIN; FERES JÚNIOR, 2006, p. 21. 
político republicano. Vol. 10. Brasília: Editora Universidade de Brasília/Câmara dos Deputados, 1981

ARENDT, Hannah. Filosofia e política. In: A dignidade da política-ensaios e conferências.

ABRANCHES, A. (Org.) Trad. Helena Martins, Frida Coelho, Antonio Abranches, César Almeida, Claudia Drucker e Fernando Rodrigues. Rio de Janeiro: Relume- Dumará, 1993.

AXT, Gunter. Constitucionalidade em debate: a polêmica carta estadual de 1891. Revista Justiça e História. Vol. 2, nº 03, p. 305-344, 2002. Disponível em: https://www.tjrs.jus.br/ export/poder_judiciario/historia/memorial_do_poder_judiciario/memorial_judiciario_gaucho/revista_justica_e_ historia/issn_1676-5834/v2n3/doc/13-Gunter_Axt.pdf. Acessado em: 28 de junho, 2016.

BARBOSA, Leonardo. BARBOSA, Leonardo Augusto de Andrade. Mudança constitucional, autoritarismo e democracia no Brasil pós 1964. Tese apresentada ao Programa de PósGraduação da Faculdade de Direito da Universidade de Brasília, 2009

CAMPOS, Francisco. O Estado Nacional: sua estrutura, seu conteúdo ideológico. Brasília: Senado Federal, Conselho Editorial, 2001.

CARVALHO, José Murilo. A formação das almas: o imaginário da república no Brasil. São Paulo: Companhia das Letras, 1990.

CARVALHO NETTO, Menelick de. Entrevista. Revista do Tribunal de Contas do Estado de Minas Gerais, Belo Horizonte, v. 65, n. 4, p. 12- 24, 2007.

COMTE, Auguste. A General View of Positivism 1957. New York : R. Speller.

COMTE, Auguste. Appel aux Conservateurs. Paris: Chez L'Auteur et chez Victor Dalmont Libraire. 1855. Dispo- 
nível em https://archive.org/details/appelauxconserv00comtgoog. Acessado em 02 de agosto, 2016.

CONSTANT, Benjamin. Da liberdade dos antigos comparada à dos modernos. In: Filosofia Política. No 2. Trad. Loura Silveira. Porto Alegre: L\&PM, 1985.

CONSTITUIÇÃO do Estado do Rio Grande do Sul de 1891. In: A Constituição Federal e as Constituições dos Estados da Republica do Brazil. Vol. I. Porto Alegre/Pelotas: Livraria Universal/ Echenique \& irmão Editores, 1895, p. 61-86. Disponível em: http:/ /www2.senado.leg.br/bdsf/item/ id/224222. Acessado em: 15 de maio, 2016.

HABERMAS, Jürgen. Direito e Moral (Tanner Lectures, 1986). In: Direito e Democracia: entre facticidade e validade. Vol. II. Trad. Flávio Bento Siebeneichler. Rio de Janeiro: Tempo Brasileiro, 2011.

HARD, Michel; NEGRI, Antonio. Multidão - Guerra e democracia na era do império. Rio de Janeiro: Editora Record, 2005, p. 192.

HOBBES, Thomas. Leviatã ou Matéria, forma e poder de um estado eclesiástico e civil. Tradução de João Paulo Monteiro e Maria Beatriz Nizza da Silva. São Paulo: Abril Cultural, 1979. (Os pensadores).

JASMIN, M.; FERES JÚNIOR, J. História dos conceitos: dois momentos de um encontro intelectual. In: JASMIN, M.; FERES JÚNIOR, J. (Eds). Historia dos conceitos: debates e perspectivas. Rio de Janeiro: Ed. Loyola: PUC-Rio, 2006.

LACERDA, Gustavo Biscaia. Elementos estáticos da teoria política de Augusto Comte: as pátrias e o poder temporal in Revista de Sociologia Política. Curitiba, 23, p. 63-78, nov. 2004.

LYNCH, Christian Edward Cyril; STARLING, Heloisa Maria Murgel. República/Republicanos. In FERES JÚNIOR, João. 
(Org.). Léxico da história dos conceitos políticos do Brasil. Belo Horizonte: Editora UFMG, 2009.

MADISON, James. O Federalista n ${ }^{\circ} 10$. In: MADISON, James; HAMILTON, Alexander; JAY, John. O Federalista. Trad. Heitor Almeida Herrera. Brasília: Universidade de Brasília, 1984, p. 417-421.

NEVES, Lucia Maria Bastos Pereira das. Corcundas e Constitucionais - a cultura política da Independência (1820-1822). Rio de Janeiro: Revan, FAPERJ, 2003.

OSÓRIO, Joaquim Luís. Constituição Política do Estado do Rio Grande do Sul: Comentário. Coleção pensamento político republicano. Vol. 12. Brasília: Editora Universidade de Brasília/ Câmara dos Deputados, 1981.

PAIM, Antonio. Introdução. In: OSÓRIO, Joaquim Luís. Constituição Política do Estado do do Rio Grande do Sul: comentário. Coleção pensamento político republicano. Vol. 12. Brasilia: Editora Universidade de Brasília/Câmara dos Deputados, 1981

POCOCK, J. G. A. O estado da arte. In: Linguagens do ideário político. São Paulo: Edusp, 2003.

RODRÍGUEZ, Ricardo Vélez. Castilhismo: uma filosofia da república. Brasília: Senado Federal, 2000. Disponível em http:/ / www2.senado.leg.br/bdsf/bitstream/handle/ id/1037/571386.pdf?sequence=4. Acessado em: 25 de maio, 2016.

RUSSOMANO, M. Victor. História Constitucional do Rio Grande do Sul: 1835/1930. Porto Alegre: Assembleia Legislativa, 1976.

SHKLAR, Judith. The liberalism of fear. In: ROSENBLUM, Nancy (Ed.). Liberalism and Moral Life. Cambridge, Massschussets: Harvard University Press, 1989. 
SILVA, Carlos Medeiros. O Ato Institucional e a Elaboração Legislativa in Revista de Direito Administrativo. Vol. 77, jul/ set, 1964. Aspas de Medeiros.

VIANNA, Oliveira. Problemas de Direito Corporativo. Rio de Janeiro: J. Olympio, 1938.

VIANNA, Oliveira. O idealismo da Constituição. $2^{\mathrm{a}}$ ed. São Paulo: Companhia Editora Nacional, 1939. Disponível em: http:/ / www.brasiliana.com.br/. Acessado em: 12 de maio, 2016.

Recebido em 24/07/2018.

Aprovado em 10/10/2018.

Francisco Rogério Madeira Pinto

E-mail: rogeriomadeirapinto@gmail.com 